\title{
Gengzi reflections: how did Chinese culture evolve in the last 180 years
}

\section{Article}

Published Version

Creative Commons: Attribution 4.0 (CC-BY)

Open access

Tang, Y. (2021) Gengzi reflections: how did Chinese culture evolve in the last 180 years. Journal of Chinese Economic and Business Studies. ISSN 1476-5292 doi:

https://doi.org/10.1080/14765284.2021.1968708 Available at https://centaur.reading.ac.uk/103082/

It is advisable to refer to the publisher's version if you intend to cite from the work. See Guidance on citing.

To link to this article DOI: http://dx.doi.org/10.1080/14765284.2021.1968708

Publisher: Informa UK Limited

All outputs in CentAUR are protected by Intellectual Property Rights law, including copyright law. Copyright and IPR is retained by the creators or other copyright holders. Terms and conditions for use of this material are defined in the End User Agreement.

\section{www.reading.ac.uk/centaur}

\section{CentAUR}

Central Archive at the University of Reading

Reading's research outputs online 


\section{Gengzi reflections: how did Chinese culture evolve in the last 180 years}

\section{Yinshan Tang}

To cite this article: Yinshan Tang (2021): Gengzi reflections: how did Chinese culture evolve in the last 180 years, Journal of Chinese Economic and Business Studies, DOI: 10.1080/14765284.2021.1968708

To link to this article: https://doi.org/10.1080/14765284.2021.1968708
(c) 2021 The Author(s). Published by Informa UK Limited, trading as Taylor \& Francis Group.

\section{曲 Published online: 19 Aug 2021.}

Submit your article to this journal

Џ Article views: 240

Q View related articles $₫$

View Crossmark data $\nearrow$ 


\title{
Gengzi reflections: how did Chinese culture evolve in the last 180 years
}

\author{
Yinshan Tang \\ Henley Business School, University of Reading, Reading, UK
}

\begin{abstract}
In its history, Chinese culture has experienced three big waves of developments. The first one was in the Warring State Period, instigated by a large number of philosophers who laid the foundations of Chinese culture. The second was the introduction of Buddhism and its final integration with Confucianism and Daoism in Southern Song dynasty (1127-1279). The third was represented by the introduction of science and social beliefs from the West (from 1840 onwards). This paper focuses on the cultural changes since 1840, from the Opium war to COVID-19 expands three Gengzi cycles. During the past 180 years, China has experienced one the most turbulent eras of its history, associated with immense culture changes. . In the recent 60 years, China has focused on economic development. The fast economic development and their response to COVID-19 have demonstrated that a system with Chinese characteristics will become the de facto system for China.
\end{abstract}

\section{ARTICLE HISTORY}

Received 27 April 2021

Accepted 27 June 2021

\section{KEYWORDS}

Chinese culture; COVID-19 strategies; post covid; culture evolution

\section{Introduction}

The Chinese use sexagenary cycles to record years. It is a cyclic numerical system of 60 years with the combination of two basic cycles; the ten Heavenly Stems and the twelve Earthly Branches. Every 60 years, there is a stem and branch combination named Gengzi (庚子), such as the years of 1840,1900, 1960 and 2020. Coincidentally, each of these years is associated with significant disasters in Chinese history. From 1840 to 2020 for the last 180 years, China has had to adjust to Western influences, primarily caused by conflict between Eastern and the Western ideologies. We have seen the path taken by the Chinese to respond to these conflicts. Upon reflection, it is now the time to understand the past so we can prepare for the future, and perhaps even help identify the guiding philosophies to prepare for the next Gengzi cycle.

\section{China in the past}

If we move back three sexagenary cycles to 1840 , this is the year that the Chinese would call the beginning of centuries of humiliation in Chinese history. This year would mark the start of the first opium war between China and Britain. The Chinese exported a large quantity of silk, porcelains and tea to Britain, and in response, the British created a successful market by 
selling opium produced in India, thus reducing the trade deficit. However, when opium started to cause social problems, the Chinese banned the trade and punished traders and smugglers. In retaliatory action, the British government sent their troops to China to protect their business interests. As a result, after having lost the war, China was forced to give away Hong Kong and other internal territories as concessions (Farooqui 2005).

Other countries quickly followed the footsteps of Britain and successfully claimed numerous locations in China as their settlements with prime rights. People settled in these concessionary territories had supreme rights above the Chinese. This triggered the anger of the local people, and foreigners were targeted with organised killings and hatred (Purcell 1963). Under the name of protecting their national citizens, these countries formed an alliance and took over Beijing by force in 1900 (O'Conner 1973), yet again another year of Gengzi. The war lasted less than a year, followed by a Xinchou protocol with the full name of 'Austria-Hungary, Belgium, France, Germany, Great Britain, Italy, Japan, Netherland, Russia, Spain, United States and China - Final Protocol for the Settlement of the Disturbances of 1900'. China agreed to pay 450 million taels of fine silver (around 18,000 tonnes, worth approx. US\$333 per tael of the time) to these 11 nations as a settlement. This protocol was regarded as unfair by the Chinese and triggered nationwide unrest, throwing the country into further chaos. Ten years later in 1911, led by Sun Yat-sen, the Qing dynasty ended to the Xinhai revolution and formed the Republic of China in the following year (Li 2007).

From 1901 to 1911, Chinese intellectuals started to reflect on the reasons why China was lagging so far behind European competitors in science and technology (Fenby 2008). They quickly started to focus on the concept that Chinese culture was 'rotten' and 'decayed', and regarded it as the root of all misfortune. They thought the only way to move forward was to abolish Chinese traditions and to fully adopt the Western system instead. People returning from Japan wanted the Chinese to follow the footsteps of Meiji restoration aiming for fast economic development. Many distinctive figures joined in on the debate on which direction China should go with conflicting opinions (Furth 1983), and it gradually became clear that certain philosophies from the West were not necessarily better than their own. They therefore started to cherry pick the ideas they believed to be suitable, whilst leaving the ones they disliked.

The western system was classified into three different categories: 1. the system that deals with nature, i.e. the scientific system; 2 . the system that deals with human beings, i.e. the social system; 3 . the system that deals with spiritual ideology, i.e. philosophies and spiritual beliefs. For category 1, the Chinese embraced the whole system as it was. To some extent, the Chinese have even put it on a pedestal and regard it as the de facto understanding of nature. For category 2 , the Chinese started to hesitate and adopted only the parts that they thought to be useful. For category 3, they concluded that Chinese traditions must remain untouched or at least showed a strong degree of resilience, i.e. hardly changing until today.

For the social management systems in category 2, Chinese only adopted some concepts such as the national management infrastructures based on law and order, economic development strategies, education systems and their supporting functions. However, there were also concepts that they did not adopt. They did not regard the Western social management system as advanced enough to compare with their own. They did not like the missionary behaviour of pushing ideological beliefs onto other societies; nor the 
expansionary endeavours of the British Empire. In Confucianism and Daoism ideology, beliefs cannot be forced onto people. This is why all spiritual monasteries or temples in China are built far from human settlements. They do not come to you, instead you will need to go to them. They also believed in benevolence; violence should be reserved as the last resort and it should be avoided whenever possible. They supported autonomous orders using the form of $\mathrm{Li}$ (礼), meaning ritual or etiquette. At the time, it was obvious to a Chinese mind that the social system they had developed for several thousand years was much more suited to China than a Western one.

Before reaching a consensus, the Sino-Japanese war started in 1937, and any intellectual arguments on ideology had to be suspended. Subsequent to that civil war then broke out, until the Communist Party came into power in China in 1949 (Zhang 2012). Since 1949 , the Chinese adopted and focused on a social system in between a full democratic system and communist ideology, naming it a socialist system with Chinese characteristics. They fashioned a system which they believed best suited for the Chinese environment and its culture. This also gained the support from the Chinese people.

This was the year that China stood up as an independent country and quickly started to chase the economic development of other countries. However, pure Communist ideology was second place to Chinese ways of thinking, and this was the direct trigger of the cultural revolution and subsequently the last attempt to move away from traditional Chinese culture. Coincidentally, just before the cultural revolution, there was another Gengzi in 1960 where China suffered a nationwide famine (Cook et al. 2014), further contributing to this Gengzi disaster. These ideological arguments were further suspended during the Korea war (19501953) and remained inconclusive. In 1978, when China started its open-door policy, ideological arguments started again with cries of abolishing traditional Chinese culture and fully adopting Western social and political systems. This time, even Chinese language was on the list to be abolished. In the other camp, there was another group of people who wanted to revert back to pure Maoist ideology which eventually ceased after Deng intervened (Weatherley 2006) by repeating his famous phrase: 'It doesn't matter whether a cat is black or white; as long as it catches mice, it is a good cat' in 1992. This marked the official pause on ideological arguments and highlighted the pragmatic thinking from Deng himself. With its open-door policy, China started to fast track its economic development by focusing on learning how to do business from developed countries.

\section{China today}

In the last 40 years, China has made impressive economic advances and is now becoming the second largest economy in the world. This success has validated the understanding in China that Chinese traditions are neither barriers towards economic success, nor do they hinder scientific knowledge and innovation. The argument on which ideology to follow seems less important when it has been proven in practice that a mixture of Chinese tradition plus certain philosophies from the West has suited the country well. The current social and political norm in China accepts this, with an increasing proportion of people supporting this line of thinking. Socialist ideologies have been integrated with Chinese cultures in a similar way as Buddhism has been merged with Confucianism and Daoism principles in the Tang dynasty, forming the Chinese version of Buddhism, the Zen or Chan (禅). 
Looking back at the last three sexagenary cycles, the wisdom that prevails is to put disagreements to the side, and instead focus on the real pressing issues. This principle has revealed a unique form of Chinese pragmatism, summarised in Chinese by the word He (和). This methodology or approach incidentally corresponds to the core principles of Managing Greyness. This approach is not based on a scientific approach, but it is especially useful to assist decision making processes when all the matters are in grey areas. Most recently, the effectiveness of this methodology has been demonstrated when dealing with the COVID-19 pandemic.

In year 2020, another Gengzi, COVID-19 has swept through China and the rest of the world. Until today, it has infected over 172 million people and caused almost 3.6 million deaths (Worldometer 2021) with the figure still increasing every day. There have been staggering human costs, notwithstanding the economic costs. The measures that different governments have taken for this pandemic can be clearly separated into two camps, one where there needs to be solid and clear scientific evidence before a decision can be made, and the other where decisions have been based on 'senses'; ready to act swiftly to modify and change the measures according to the situation. Results shown that the most effective measures that have reduced virus transmission on a large scale was the latter. It is worthy to note that a timely decision to have a nationwide lockdown based on very limited information was not easy to follow or even to be understood by the first group. The time needed to allow scientists to collect enough data and reach a conclusion was evidentially too late. Most governments struggled to decide which measure to choose as they could not find a balance between stopping the transmission of the virus, and keeping the economy moving whilst maintaining good social order. We may still remember the days of arguing if face masks were necessary or not. In comparison, the decisionmaking process that China took was relatively smooth - face masks, lock down, isolation, treatment policies were all put in place quickly. It seemed that the Chinese government could make decisive decisions based on 'senses'; however, they were also aided by the fact that the Chinese people accepted such decisions without much resistance. As the pandemic was first identified in China, everything related to this disease was unknown. Facing such challenge, the Chinese government had to make quick decisions based on previous experiences with SARS from 2002 to 2004. In such situations, the traditional Chinese way of thinking of focusing on the pressing matter, choosing whatever measures which may work, and ready to make changes or improvements in the process has proven to be effective. Those steps sound simple, but they really reflect the Chinese thought processes on how to manage uncertainties in a similar principle as Deng Xiaoping's black and white cat philosophy. It is a good example of 'Managing Greyness'.

This methodology, like Chinese medicine, is regarded as unscientific from a purist's point of view. In principle, the scientific approach of management is usually based on using all possible methods and tools to convert uncertainties into clarities or to identify the main factors or assess the main trends in order to make a decision. Whilst we are choosing the methods to achieve the desired results, we again need to understand the effectiveness of each measure before we can make a decision. This difference can be found in many cross culture-related project management jobs. For example, in my years of experience of establishing education collaboration projects with Chinese universities, this difference in viewpoints can be cause for serious misunderstanding. When a collaboration project has been agreed by senior management teams, the Chinese mindset would usually regard this as $90 \%$ of the job done; all the 
details can be worked out later. In comparison, a British University may just regard this as less than $10 \%$ is accomplished. They would rather treat this as the starting point. Before the contract can be signed, teams must go through many internal compliance procedures to seek agreements from all stakeholders. This would always cause the Chinese partners to question why these issues need to be dealt with upfront - e.g. checking student accommodation, library, administration, admissions, marketing, health and safety, IT services, canteen etc, and cause them to wonder if they are losing sight of the main purpose of the collaboration.

China has spent the last half century trying to catch up to the developed countries, and to some extent is still in that mindset. As China's economy gets closer and closer to the USA, it has resulted in Sino-American tensions which have started to play out on the world stage; through sanctions, trade wars and conflicting interests in the region. However, the Chinese are using different guiding philosophies which may not be suited for a proactive leading position. Throughout history, it has been China's preference to keep internal matters internal, and leaving other nations alone unless provoked, which is the state that Laozi has described as: 'neighbouring nations face each other, chickens and dogs may hear each other squawk and bark, but may the common people never need to fight (邻邦 相望, 鸡犬之声相闻, 民至老死不相往来)'.

\section{China in the future}

According to economists, China will become the largest economy in the world in 5-10 years (CEBR 2021). The real challenge, however, is how do the existing superpowers react to this shift. Countries in the world are siding with either the USA or China based on self-interest, domestic and ideological matters. Meanwhile, China has started to take a more assertive stance in the world stage, demonstrated by endeavors like the Belt and Road initiative, expanding influence across developing countries and gaining allies. This has been in response to the perceived threat posed by the USA, whether justified or not.

Currently, there is a stark difference between opinions of the West and within China. Within Western countries, there is a perceived threat to democracy, free speech and Western values. Within China, there is a growing sense that their economic success is deserved, and their methods justified, especially after hundreds of years of humiliation by colonial forces. Culturally, any criticism of China reflects on the country and its citizens, and recent events have shown that the Chinese are very willing to withdraw funding and investments based on any perceived slight. From a Western perspective, this can be surprising, and demonstrates again a lack of understanding and difference in culture, especially when it comes to the relationship of its people and the state. Perhaps this difference in viewpoint has been further been exacerbated by the difference in language, and the separation of the internet. Our understanding of America, for example, comes through Hollywood, social media, the internet. For someone who has never visited China or doesn't understand the language, it is truly difficult to gain common ground, or even imagine a world where cultural beliefs and systems are so different.

For China, a new philosophy should be considered. As China gains more influence in the world stage, it will require more collaboration and understanding of different viewpoints now more than ever. They should have the courage to adopt scientific methodologies and other ideologies from the rest of the world, as well as recognising that Chinese cultures and traditions have a place in society. Communist principles have served China's development 
well; however, further adapting and exploring all sources of knowledge can be used to guide China for next 180 years. China will need to find a balance between retaining its Chinese culture whilst becoming more open to new ideas. The new guiding philosophy should serve China to move forward not only economically, but to prepare for a time when accumulation of wealth has reached its limit, when spiritual enlightenment becomes the next era. The world can no longer sustain the rate of human development in its current form, and leading this line of thinking would help the rest of the world to understand China. An inclusive philosophy based on all forms of existing human intelligence, which encompasses all aspects of physical, human and spiritual sphere would be the benefit for all.

\section{Further notes}

Historically, China's dominant philosophies have experienced three major advancements in thinking. The first one was between $770 \mathrm{BC}$ and $256 \mathrm{BC}$, an era of foreign invasions and civil wars, as well as exciting philosophical and cultural developments. The most important philosophies, beliefs, ideologies and approaches all appeared during this time. The second one was from 184 AD to 581 AD. During this period, Buddhism spread to China and was successfully integrated with local Daoist and Confucian beliefs. Foundations for a feudalist society was laid and lasted over 1500 years. The third advancement in thinking is what I have covered in this article. The introduction of Western ideologies and scientific methodology into China has played a significant role in China's success. I envisage an era in the future where further advancements are made, to prepare for the challenges that lie ahead.

Upon further reflection, readers may feel that I am taking a stance that this is China versus the rest of the world. I have no intention to put China on one side against another but the main purpose of this article is to explore the Chinese way of thinking when compared to the West. I wrote this article in response to a conversation of how disasters seem to be triggered always in the years of Gengzi (especially in the last 180 years of Chinese history). This article is speculative, and perhaps not 'scientifically' sound. It is rather a collection of personal opinions. More than ever now the world is in need of collaboration, and truly understanding each other and how we are shaped by different cultural contexts is important to make that next step.

\section{Disclosure statement}

No potential conflict of interest was reported by the author(s).

\section{Notes on contributor}

Professor Yinshan Tang is a Vice Dean of Henley Business School, University of Reading, UK; a Professor in Management Informatics. He obtained his PhD degree at Imperial College London in 1994. He then had two terms of postdoctoral experiences in Universidad de Los Andes, Venezuela and Keele University, UK. In 1998, he joined a business consulting company managing a business unit for almost 6 years before joining the University of Reading helping to establish Informatics Research Centre in 2004. His research is multi-disciplinary which covers the fields of management and biology. He has brought in the concepts of management ecology, innovation ecology and innovative nation. His current focus is in cross culture management with special interest in 
'managing greyness' as management theory and practice.His other research interests focus on the philosophies of artificial intelligence, digital ecosystem, digital transformation, world peace index, management philosophies and practices.

\section{References}

CEBR. 2021. Accessed 2 June 2021. https://www.theguardian.com/world/2020/dec/26/china-toovertake-us-as-worlds-biggest-economy-by-2028-report-predicts

Cook, J. A., J. Goldstein, M. D.Johnson, S. Schmalzer. 2014. Visualizing Modern China: Image, History, and Memory, 1750 - present. Lexington Books. ISBN-13: 978-0-7391-9043-2, ISBN: 0-7391-9043-1. New York, London.

Farooqui, A. 2005. Smuggling as Subversion: Colonialism, Indian Merchants, and the Politics of Opium, 1790-1843. Lexington Books. ISBN 0-7391-0886-7. New York, London.

Fenby, J. 2008. The Penguin History of Modern China: The Fall and Rise of a Great Power. Penguin Books. ISBN 978-0-7139-9832-0. London.

Furth, C. 1983. "Intellectual Change: From the Reform Movement to the May Fourth Movement, 1895-1920". In Republican China 1912-1949, Part 1, pp 322-405. The Cambridge History of China, edited by J. K. Fairbank. Cambridge: Cambridge University Press. ISBN 978-0-521-23541-9. London, New York, Melbrourne.

Li, X. 2007. A History of the Modern Chinese Army. The University Press of Kentucky. ISBN 0-81312438-7, ISBN 978-0-8131-2438-4. Kentucky.

O'Conner,R. 1973. The Boxer Rebellion. Robert Hale \& Company.ISBN 0-7091-4780-5. London.

Purcell, V. 1963. The Boxer Uprising: A Background Study. Cambridge University Press. ISBN 978-0521-14812-2. London, New York.

Weatherley, R. 2006. Politics in China since 1949: Legitimizing Authoritarian Rule. Routledge Taylor \& Francis Group. ISBN 978-0-415-39109-2. London, New York.

Worldometer. 2021. Accessed 2 June 2021. https://www.worldometers.info/coronavirus/

Zhang, M. 2012. 《重说中国近代史》. ISBN978-988-15884-4-9. 文史中国 香港第一版: 香港中和出 版. 